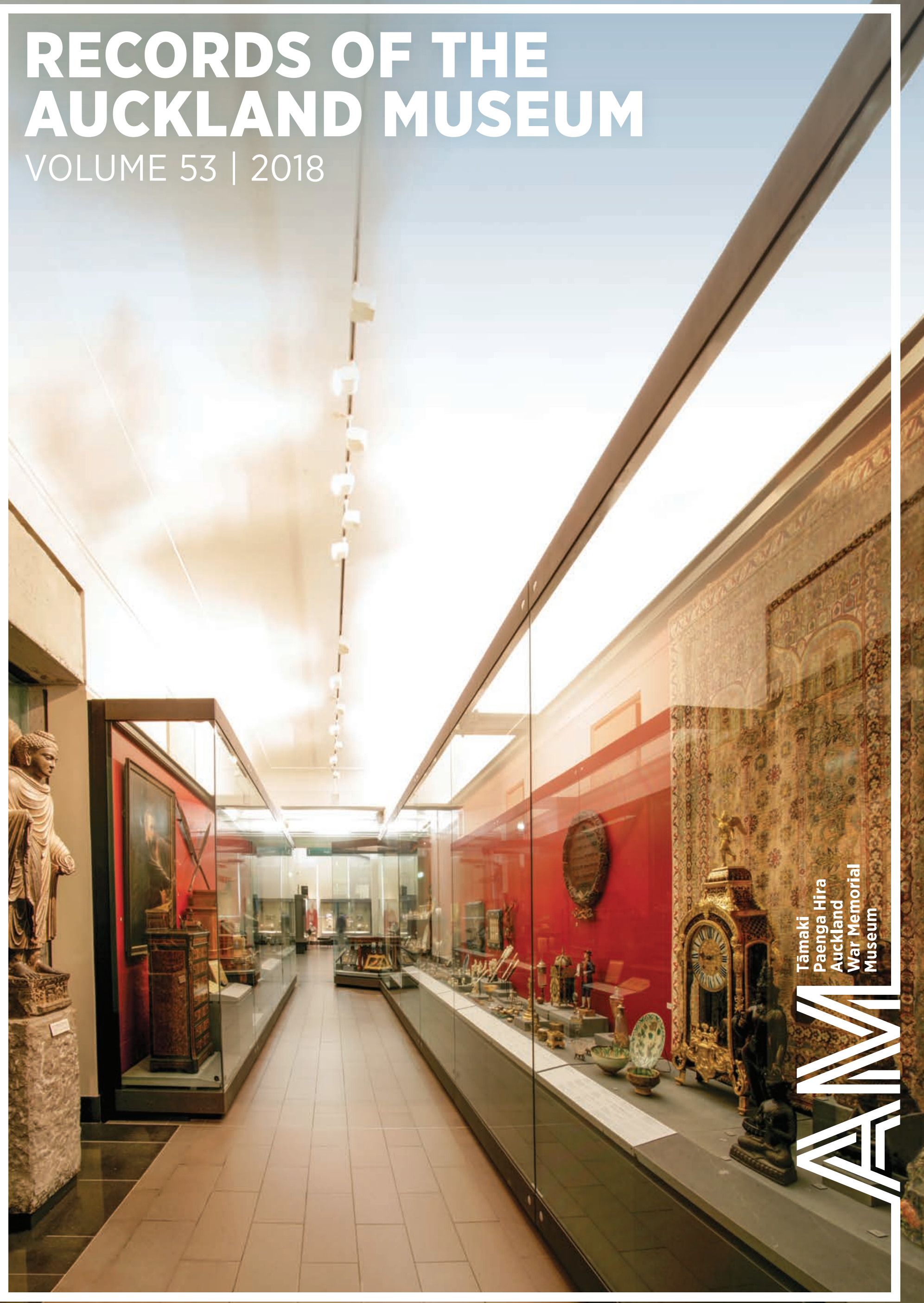




\title{
Preserving a legacy: an analysis of the role and function of the Mackelvie Trust Board, 1885-2010
}

\author{
Andrew McKay University of Auckland
}

\begin{abstract}
Established to manage the art collections of one of Auckland city's former businessmen, the Mackelvie Trust Board has operated for over 125 years. The Trust was set up to administer James Tannock Mackelvie's (1824-85) collection of European paintings, books, decorative arts and objets de vertu including bronzes, clocks, coins and natural treasures now held at the Auckland Art Gallery, the Auckland War Memorial Museum and the Auckland Public Library. This article will explain how part of the collection came to be at the Auckland War Memorial Museum, how the Trustees administered the will, and how the Trust Board itself evolved to include professional expertise. The impact of this evolution on Mackelvie's gifts and bequest and the collection's development is one of the most important findings. After an evaluation of the collection's management over time, it is concluded that while the Mackelvie Trust Board has always endeavoured to implement Mackelvie's wishes, financial and physical restrictions led to certain compromises regarding control and display of the collection. Nevertheless, the Trustees have always acted in good faith and protected Mackelvie's legacy for the enjoyment of future generations of Aucklanders and visitors to the city.
\end{abstract}

\section{Keywords}

Mackelvie Trust Board; Auckland Institute and Museum; James Tannock Mackelvie.

\section{INTRODUCTION}

The subject of this study, James Tannock Mackelvie (born Glasgow, Scotland, 1824 - died London, England, 1885) was a man known to enjoy the good things in life (Fig. 1). To a friend, Mackelvie wrote "all I ever wanted was $£ 5,000$ a year, and nothing to do but spend it" (Carroll 1994). Art was his passion, and the people of Auckland have become the main beneficiaries of his ability to indulge this interest. During Mackelvie's six short years in Auckland (1865-1871) he acquired a substantial fortune (estimated at $£ 60,000$ ). With a strong sense of civic duty, Mackelvie was a founder of the Acclimatisation Society, which formed the botanical garden in the Domain, and was an inaugural member of the Auckland branch of the Philosophical Society in 1867 . This organisation changed its name the following year to become the Auckland Institute and Museum (Stacpoole 1985).

On his return to London, England in 1871, he purchased a substantial inner-city residence near Victoria Station, London. As the centre of the art world, it was the ideal base for a gentleman collector of means, and over the next fourteen years Mackelvie undertook his own 'Grand Tour', and built an extraordinarily diverse collection of "paintings, sculptures, bronzes, ivories, jades, enamels, porcelain, clocks and watches, coins and medals, arms and armour, books, mosaics, bonbonnieres, rock crystal and glass" that he intended be used to form a teaching collection in Auckland (Stacpoole 1985: 7). He also built up a fine collection of books, along with archaeological and ethnographic artefacts that were gifted to the Auckland Institute and Museum prior to his death. ${ }^{1}$ This latter collection comprised prehistoric materials found in settlements along the shores of Swiss lakes such as stone adzes, pottery, knives and spindles gifted in 1883 in order that the Auckland Institute and Museum have truly encyclopaedic collections (Stead 2001). All of the artefacts, artworks and publications that Mackelvie amassed are now owned by, or entrusted to, Auckland's three key cultural institutions - the Auckland Art Gallery, the Auckland War Memorial Museum² and the Auckland

1 Mackelvie bequeathed some 500 books, which included volumes with superb lithographs, and a book of specimens of tapa cloth brought back from Captain Cook's third Pacific voyage. More than half of the book collection focussed on the early history of the colony, and was sent to the curator and secretary of the Auckland Institute and Museum, Thomas Frederic Cheeseman, between 1877 and 1884.

2 In 1997 Auckland Institute and Museum changed its name to Auckland War Memorial Museum to reflect the changed legislation-mandated governance structure. The majority of references in this paper refer to Auckland Institute and Museum, or Auckland War Memorial Museum, but for simplicity the name Auckland Museum is used throughout. 


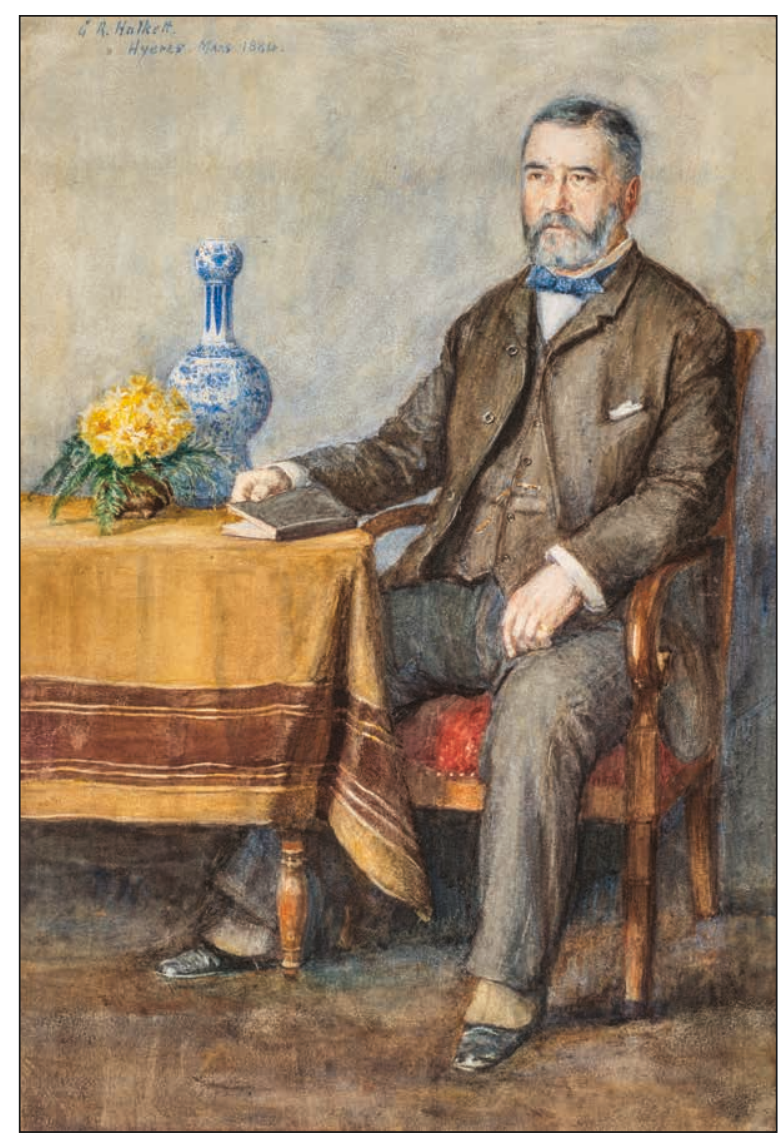

Figure 1. George Halkett, James Tannock Mackelvie, 1884, watercolour Mackelvie Trust Collection, Auckland Art Gallery Toi o Tāmaki, bequest of James Tannock Mackelvie, 1885. M1885/1/32

Public Library. Mackelvie was a methodical man and kept meticulous diaries, letter-books and inventories of his collection. Fortuitously for the future Trustees of his collection, he would prepare and publish, just prior to his death, the Catalogue of the Mackelvie Collection for Auckland, New Zealand, 1885. Wanting his legacy to be maintained, Mackelvie also commissioned oil, watercolour and photographic portraits of himself, and prepared a will that stipulated that his collection would be placed in Trust and administered by an independent committee tasked with the responsibility of adhering to the terms of his will after his death.

\section{ADMINISTERING THE WILL}

Back in London in 1877 Mackelvie had his lawyer draft his will shortly after he had made his first gift of Jardine's Naturalist's Library to the Auckland Public Library. Even though he was a single man with no immediate family, he kept the terms of the will confidential to ensure that no one would pressure him to change his vision for the civic repositories of Auckland being the recipients of his collection (Will 1877). After his death eight years later in June 1885, Mackelvie's will provided small legacies for his sister, nieces and nephews, but left the bulk of his assets to a trust to be set up in his name - The Mackelvie Trust. The will specified that four Auckland-based Trustees - the banker David Limond Murdoch (1885-1911), artist Albin Martin (1885-1888), businessman and philanthropist John Logan Campbell (1885-1912) and lawyer-financier Thomas Russell (1885) - be appointed as executors of the Trust and "shall stand possessed the said pictures, prints, bronzes, statues, vases, works of art, articles of vertu and curiosities... bequeathed to them" (Will 1877: 10).

Mackelvie's will (1877) also specified that any residue monies from the estate be used to "purchase or acquire a site in or near the city of Auckland in New Zealand suitable for the erection of a building... and cause to be erected on such site a museum capable to receive and display the said collection" (Will 1877: 11). Mackelvie favoured a site in the expansive grounds of Government House in Waterloo Quadrant, near to the Auckland Museum in Princes Street (Fig. 2). Three years before his death, Mackelvie wrote a letter to Thomas Cheeseman outlining this proposal:

"My idea has always been that as Auckland is no longer the seat of Government, Government House does not require so much vacant ground around it, and that a part of it should be used for the erection of an Art Gallery for the benefit of the inhabitants. I quite agree with Sir George Grey's idea of erecting a large building by degrees on that ground, and I hope it is not too late to abort it. I also agree with you as to the folly of a number of separate institutions all over the town, requiring no end of expenditure to look after them." (Mackelvie 1882)

While Cheeseman had been appraised of Mackelvie's wishes prior to his death, Mackelvie's stipulation that the collection had to be housed in a building specifically erected for the purpose both surprised and caused consternation to the Auckland City Councillors who received copies of his will. Mackelvie believed that housing his collection in its entirety in a purpose-built structure would preserve its integrity. This idea was at variance with what the City Council had previously been led to believe: that Mackelvie would bequeath his collection to the City Council unencumbered (Garrity 1975). It was this assurance, along with Sir George Grey's promise to donate his sizeable collection of books and manuscripts, which was the catalyst for the competition to design Auckland's first Free Public Library and Art Gallery in 1883. The French Châteaustyle building was designed by Melbourne architects John H. Grainger and Charles A. D'Ebro, and the foundation stone for the building was laid at the corner of Coburg (now Kitchener) and Wellesley Streets on 4 June 1885 (also coincidentally the date of Mackelvie's death in London). The Auckland Free Library and Art Gallery opened to the public on 17 February 1888 . To accommodate Mackelvie's collection, significant alterations were made to the design of the art gallery section of the building and a wing added to create The Mackelvie Gallery, specified to be attached to the Free Public Library and Art Gallery. It was not until the construction of a new central library building in 1971 that the Mackelvie and Grey book collections were separated and allocated to the Auckland Public Library. 


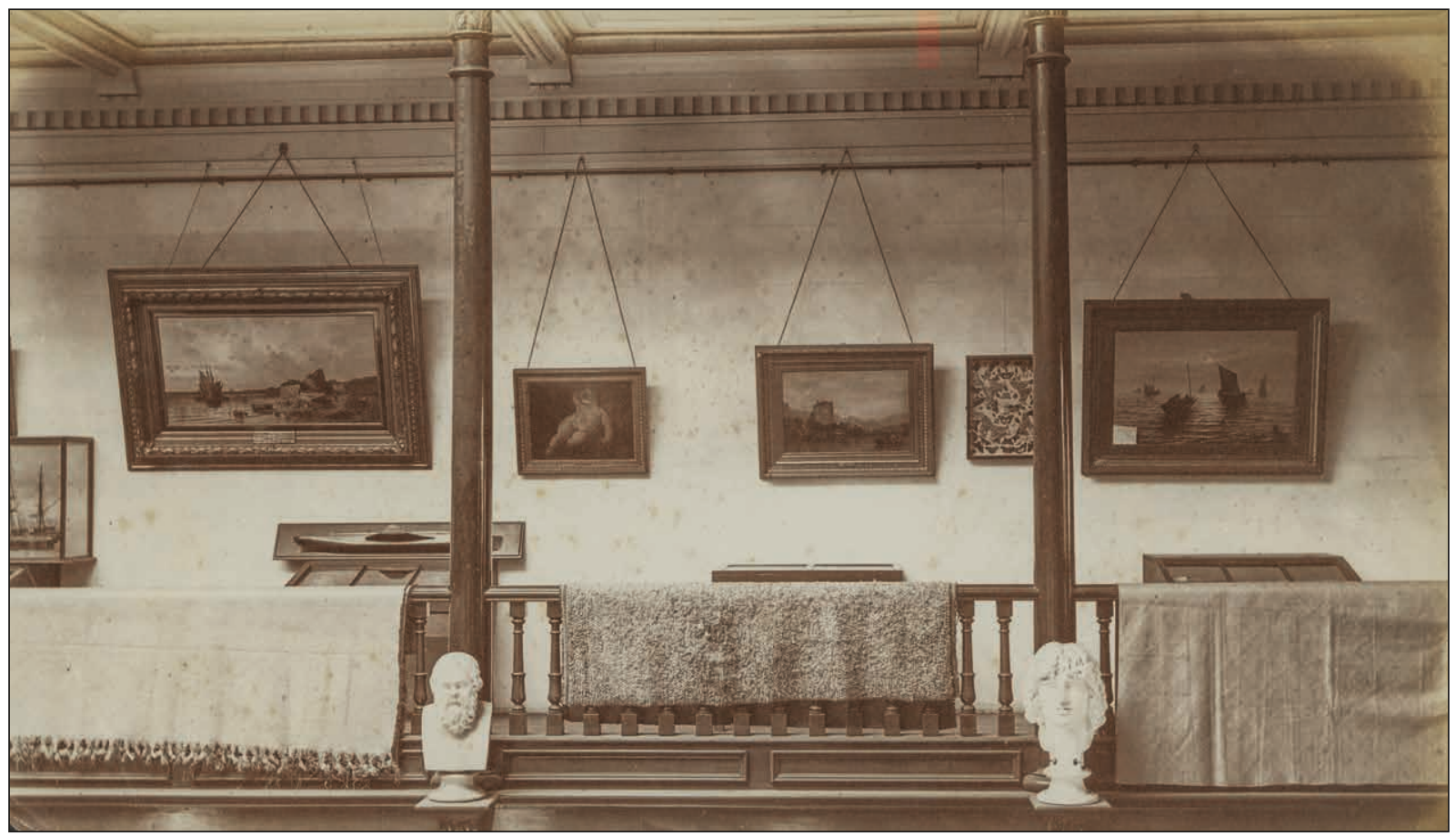

Figure 2. Mackelvie Collection, Auckland Museum, Princes Street, c. 1882. Print, Ph-NEG-SL780, Auckland War Memorial Museum.

Another condition of Mackelvie's will was that the public be granted free access to view his collection, including on Sundays. To support this, further sums of $£ 2,000$ and $£ 1,000$ were to be invested with the income derived providing salaries for custodians, and also pay for maintenance and insurance of the gallery. Any remaining surplus was to be allocated for the "purchase, transport and arrangement" of art or objects to add to the existing collection (Will 1877: 12). It would be this last provision, the requirement that the Trustees make acquisition decisions, which would prove most problematic.

Unfortunately a global economic downturn during the mid-1880s decreased the value of Mackelvie's property and shares, ending speculation about a dedicated gallery being constructed: the $£ 10,000$ allocated in the will for gallery construction costs had depreciated to about half its value. That would suffice only to purchase a site and erect a building, with no funds left to invest to pay staff, maintain or build on the collection (Vennell 1971). This meant that the Trustees were left in the position of having the authority, but not the means to administer the terms of the Trust. For the next eight years, the problem of how to resolve this dilemma became their main focus. As a result, the majority of his bequested collection, which had arrived from England in 1887, was held in the bonded store of Brown and Campbell in Shortland Street, and was unable to be enjoyed by the public as Mackelvie had envisaged.

The High Court of Justice, Chancery Division, in London approved the 'scheme' to amend the relevant provisions of the will so that Mackelvie's collection could be housed in a wing attached to the new municipal art gallery. The favourable ruling required confirmation by the Supreme Court of New Zealand (which was duly given in 1892) that whilst still giving "practical effect to the intentions of the testator," the Trust was relieved of the costly burden of constructing its own dedicated Mackelvie building (Will 1877: 26). This momentous decision released the capital necessary to purchase art for the collection. The numerous boxes stored at Brown and Campbell's premises could be unpacked and the contents finally put on display in the new 'Mackelvie Gallery' in 1893.

The Mackelvie Gallery within the Free Public Library and Art Gallery was not large and a lack of wall space to display artwork soon became a major issue. Following extensions in 1912 and 1916, the building was able to accommodate more artworks and decorative arts items. Acquisitions could consequently be made for both the City and Mackelvie collections. By 1922, further variations were made to Mackelvie's will that superseded the 1892 scheme. Roles were defined: the City Council would control the buildings while the Trustees maintained control of the collection. Alarmingly, a new clause was added to the will allowing the City Council the right to give "the Trust Board two years' written notice to remove the Mackelvie collection from the said buildings," if so desired (Mackelvie Trust Board Papers 1922: 3). This clause has never been invoked, however.

Still the conditions for display of the burgeoning Mackelvie collection remained cramped in the art gallery building, and in 1923 it was suggested that the Mackelvie Trust Board relocate the entire collection to the proposed Auckland War Memorial Museum which 
was to be built in the Domain. The Trust rejected this idea on the basis that an art gallery provided the proper viewing conditions for the largely pictorial collection (Vennell 1971). However, Dr Gilbert Archey, (later Sir) (1890-1974), Director of the Auckland Museum emphasised the desirability of having the decorative arts in one building as a single comprehensive display. In 1931 Archey offered a solution to the space issue when he approached the Mackelvie Trustees asking for all the pieces from the Mackelvie decorative arts collection for display in the newly-constructed museum which had opened in 1929. This offer was accepted on the proviso that the items be displayed in a dedicated space and be clearly labelled as on loan from the 'Mackelvie Trust' collection, and that they would be returned to join the rest of the collection at the Auckland Art Gallery on demand.

In 1955, the Auckland City Council proposed an internal agreement that would divide the Mackelvie artwork collection into groups to be exhibited in rotation, with the Auckland Art Gallery having the authority to include Mackelvie artworks in temporary exhibitions curated by its professional staff. In addition, the Board would be encouraged to exhibit portions of the collection throughout the Province of Auckland (Mackelvie Trust Board Papers 1955). In keeping with the terms of the will, the art displayed was required to be clearly labelled as belonging to the Mackelvie Trust collection, with conditions regarding free access to be observed (Agreement on Mackelvie Art Collection 1955). It was decided that a private bill be introduced into Parliament "to give effect to the new agreement" which would allow the Mackelvie Trust Board wider powers to utilise the collections held in the three cultural institutions in Auckland (Vennell 1971: 36). After much expensive consultation with lawyers, this bill was finally drawn up and introduced into the House of Representatives in August 1958. It became law the following month as the Mackelvie Trust Act 1958 and remains on the statute books today.

\section{AGENCY AND FUNCTION OF THE MACKELVIE TRUST BOARD}

A key focus of the Mackelvie Trust Board, particularly during the first half of the 20th century, was on improving the environmental conditions for the display of their collection in the Mackelvie Gallery. The Victorian-era Auckland Art Gallery lacked temperature and humidity control. The temperature variation, especially during the peak summer and winter periods, soon caused considerable damage to a number of the paintings. At a meeting of the Trustees in 1917 a temporary solution was found and artist (and inaugural director of the Elam School of Art) Edward Payton (1859-1944) was authorised to clean mildew off the paintings (Mackelvie Trust Board Papers 1917). However, such cosmetic treatment did not address the cause of the problem. In 1927, a heating system, paid for by the Auckland City Council, was finally installed. Unlike the painting collections, the decorative arts in the Mackelvie Collection were not affected by such poor environmental conditions. This included wooden furniture [display cases and vitrines] which benefitted from the modern storage conditions at the new museum building in the Domain to which it was relocated in 1931.

These changing circumstances for the collection often occasioned the production of a catalogue or inclusion of the Mackelvie Collection in an Auckland Museum or Auckland Art Gallery publication. The catalogue Mackelvie compiled just prior to his death in 1885 was subsequently amended and republished, particularly during the earlier years of the Trust, when new items were acquired or sold from the collection. The publication of catalogues served not only a practical purpose - to provide the most current inventory record of the collection - but also educated the public on the contents of the Mackelvie Collection itself. Publications on the collection helped improve its visibility as an entity. In The Centennial History of the Auckland Institute \& Museum 1867-1967 A.W.B. (Baden) Powell, assistant director of the Auckland War Memorial Museum from 1936 to 1963 , outlined the importance of the Mackelvie collection to the museum. Powell writes that the Mackelvie collection "has added pieces in every field, many of superb quality," in particular its assembly of watches and clocks, with an "emphasis on the history of clock-making rather than novelty," a range of European 18 th-century snuff boxes, an 18th-century lacquer chest and numerous Oriental ceramics (Powell 1967).

Further opportunities to publicise the collection included exhibitions in 1971 to mark the centenary of the city of Auckland. This included a display of Auckland landscape paintings in the Gallery along with the exhibition 'Auckland 1871' comprising objects of china, glass and silver in the Museum (Gamble 1971). A further exhibition followed in 1985, jointly curated by the Auckland Art Gallery curator Andrew Bogle and Auckland Museum's Curator of Applied Arts Brian Muir, to commemorate the centenary of Mackelvie's death. This exhibition was spread over both institutions, with displays at both the Auckland Art Gallery and the Auckland Museum (Fig. 3). During this time, a centennial display was also held in the Rare Books Room of the Auckland Public Library of select books from the Mackelvie book collection. This display reflected Mackelvie's great interest in the arts, and included fine examples of 19th century illustrated book production such as wood and copper engraving, etching, lithography and hand colouring (The Mackelvie Collection 1985). By this stage, the Mackelvie Collection had grown to approximately 2,500 items in the Art Gallery and 900 in the Museum with about 500 books in the Public Library (Mackelvie Trust Board Papers 1984). It was agreed that only the best of the Mackelvie Collection and works not often displayed were to be featured in the centenary exhibition with "the emphasis in each case... on the cream of the collections" (Mackelvie Trust Board Papers 1984). An event of this scale was testament to the individuals on the Board at the time who had the organisational ability, public relations skills and commercial savvy. These combined to ensure that the Centennial Exhibition became a pivotal moment in the history of the Trust. 


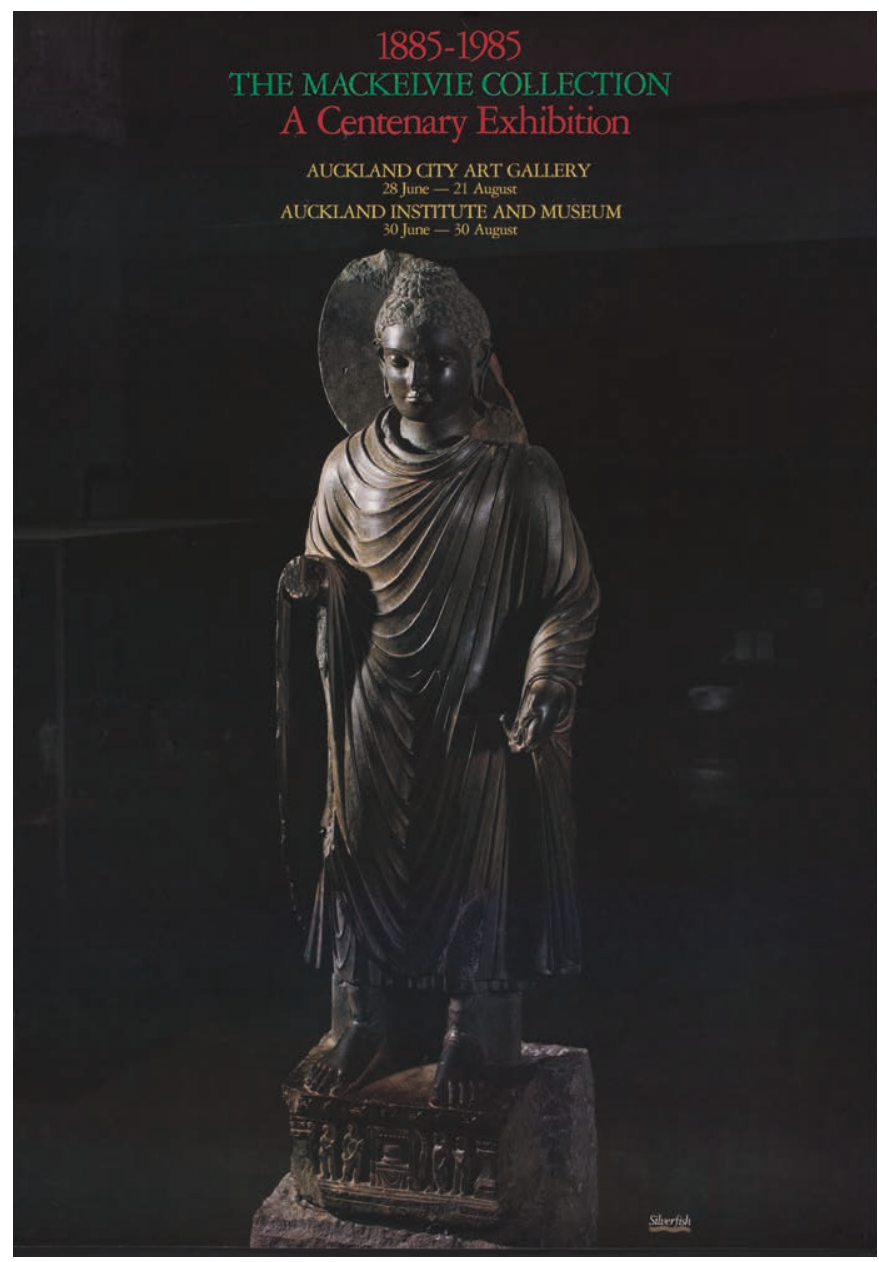

Figure 3. Poster from the Auckland War Memorial Museum. The Mackelvie Collection 1885-1985. A centenary exhibition. EPH-PT-6-61.

\section{COLLECTION MANAGEMENT}

Recognising that there was no expertise in art acquisition or curatorship amongst the initial complement of Trustees, the Mackelvie Trust Board, via connections in London, appointed a series of art buyers to assist with the purchase of pictures in London during the early twentieth century. These included the Scottish artist Sir George Reid (1841-1913), President of the Royal Scottish Academy, and the English-artist (and member of the Royal Academy) Marcus Stone (1840-1921). ${ }^{3}$ These men were selected based upon their reputation in art circles with the Trustees placing considerable faith in the ability of these men to purchase paintings representative of key developments in British art and therefore suitable for the educational purpose of the collection. Consequently there was little or no guidance as to what to buy but plenty of

3 In 1897 Mackelvie Trustee David Murdoch wrote to the English-artist Marcus Stone requesting his services as art agent for the Mackelvie Trust Board in London. Stone had recently married Laura Brown, the daughter of John Logan Campbell's business partner William Brown. money, derived from income received from the Trust's investments in property and debentures.

By the early 1920s, the Trustees, for no apparent reason, terminated the arrangement with their London agents, and instead decided themselves to make a series of purchases for the collection. This proved to be an unwise decision as many of these purchases during this period came to be assessed by later Trustees as poor choices which indicated that expert advice was necessary. Edward Payton (1859-1944), the former director of the Elam School of Fine Arts, who was concerned about the excessive quantity of Victorian paintings and the overall quality of the acquisitions made by the Trustees became an agent for the Board in 1930. He was sent to Europe with the authority to spend up to $£ 6000$ on paintings, focussing on "French, British, Cornish and Scottish works" (Stacpoole 1985: 11). However, Payton's purchases received a torrent of criticism when they were displayed in the gallery on his return. Irish playwright George Bernard Shaw (1856-1950) who visited the Auckland Art Gallery in 1934, exclaimed "Bonfires! What you need is some nice big Bonfires!" when asked his opinion of the Mackelvie collection (Fairburn 1947: 56). 
From 1885 until 1930 over $£ 16,000$ was spent by the Mackelvie Trust Board in acquiring English paintings for the collection, a huge amount of money to spend on art at that time. The combination of the Board's laissez faire approach to planning acquisitions and a lack of art knowledge among the Trustees themselves unfortunately resulted in a high number of poor quality works entering the collection.

In 1944 the situation took a turn for the better. The Chairman of the Mackelvie Trust Board Sir Cecil Leys (1877-1950), proposed that the English-born farmer, sculptor and President of the Auckland Society of Arts, Richard Oliver Gross (1882-1964) join the Trust (Mackelvie Trust Board Papers 1944). As a sculptor, Gross sought to address the lack of sculpture in the Mackelvie collection by acquiring a number of important bronze figurative sculptures including Aristide Maillol's The Woman who walks through the water in 1957 (Stacpoole 1985). The Board sought assistance with the purchase of the Maillol nude bronze from Gilbert Archey, Director of Auckland Museum, and with a donation from the National Art Collections Fund, they acquired it for $£ 2,700$ (Mackelvie Trust Board Papers 1957). In addition to Gross, Leys sought to extend the range of advisers to include John Rothenstein (1901-1992), the Director of the Tate Gallery in London, and the Australian newspaper executive and governor of the Art Gallery of South Australia in Adelaide, Sir Frederick Lloyd Dumas (1891-1973). Both men provided excellent advice on acquisitions.

\section{PROFESSIONAL STAFFING CHANGES}

Changes in staffing at the Auckland Art Gallery affected the direction in which the Mackelvie collection was developed during the immediate post-war period. In 1952, Dr Eric Westbrook (1915-2005), an English-born artist and curator was appointed as the first professionally trained director. The Trustees felt that the "greatest difficulties of maintaining the Board's collection would almost automatically disappear" (Mackelvie Trust Board Papers 1951). Westbrook was seen as someone who could take the Auckland Art Gallery and its collection, along with the Mackelvie art collection, to the next stage in its journey.

Westbrook ensured that it was his sole responsibility as Art Gallery Director to select the pictures to be exhibited, with the Mackelvie Trust Board reserving the right to select those for display only in the Mackelvie Gallery. This arrangement continued under Westbrook's successor, the art historian and academic Peter Tomory (1922-2008), who was instrumental in introducing professional standards to the Art Gallery during his directorship from 1956 until 1964 (Brown 1981). Tomory quickly set up a conservation laboratory at the Art Gallery to redress the neglect of the Art Gallery's collection, and Mackelvie Collection works were also treated by the conservator Les Lloyd. Considered to have a good first-hand knowledge of the London art market, Tomory immediately put in place a robust policy for the acquisition of art works that included the Mackelvie collection. He determined that the Mackelvie Collection could benefit from some judicious deaccessioning which would improve its coherence and also permit a greater rotation of the collection for display. If the works were sold on the open market, this would also release capital that could be put to use to acquire new works.

The controversial culling of the collection that resulted was not limited to items in the Mackelvie Gallery at the Auckland Art Gallery. Mr T.J. (Trevor) Bayliss, inaugural Curator of Applied Arts and later Assistant Director of Auckland Museum, wrote to the Mackelvie Trust Board on more than one occasion proposing that items which had "no real museum value" be disposed of (Mackelvie Trust Board Papers 1968). In 1975, for example, Bayliss suggested a review of the museum's Mackelvie collection objects, with the revenue from the sale of the collection items to fund the purchase of a pair of Tang Dynasty Urns (Mackelvie Trust Board Papers 1975). Although this purchase did not eventuate, it indicates that Bayliss (who was an expert in British and European ceramics, and writing a guide to the Museum's ceramic collection), recognised that there were many inferior pieces in the Mackelvie Collection. A detailed inventory was eventually compiled of all items in the Mackelvie Collection held by Auckland Museum and forwarded to the Mackelvie Trust Board. The inventory showed weaknesses in the museum's [Mackelvie] collection of silver (Mackelvie Trust Board Papers 1987). Trustee Dr Lindo Ferguson recommended that the Board investigate local silver purchases (of English or New Zealand objects), and solicit donations from any local silver collectors of the same. Subsequent additions to the Mackelvie silver collection included a pre-1899 Fabergé bell push made of gold, silver, enamel and ruby (1991) and an 1875 English silver ewer (1992).

In the $1970 \mathrm{~s}$ and $1980 \mathrm{~s}$ the Trustees were - in the opinion of John Stacpoole - pure amateurs, "a group of people who had a liking to art" (Stacpoole 2017). ${ }^{4}$ During these decades, the Mackelvie collection continued to focus on acquiring foreign paintings, while the acquisition of New Zealand works was the responsibility of the Auckland Art Gallery staff. This differentiation constrained the number of acquisitions made by the Board as it was a period where the price of international art work had escalated dramatically, making it difficult for them to acquire works. In order to generate funds to purchase new works, the Trustees continued to deaccession inferior collection items, discreetly auctioning off selected paintings and objects.

Most of the collection development was centred on the paintings in the Art Gallery, however the Trustees did occasionally buy decorative art pieces for Auckland Museum, to correct perhaps an historical imbalance across the collection. This occurred more frequently from the 1960s when Dr Gilbert Archey recommended that the Mackelvie Trust Board use the museum's agents in London to identify items of furniture for acquisition (Mackelvie Trust Board Papers 1960). ${ }^{5}$

4 John Massy Stacpoole OBE (1919-2018) was a Mackelvie Trust Board Trustee (1972-2008) and Chairman (1974-1990).

5 During this period these London-based agents included the fine arts dealers Thomas Agnew \& Sons and Roland, Browse \& Delbanco. 
Through such agents, they acquired a significant 18th-century lacquered chest-on-chest with decorative Chinese panel inserts, made by the firm of Elizabeth Bell in London, which was purchased for an undisclosed sum in 1963, and the sculptured Indian Gandharan figure of Buddha c. AD 200 (Fig. 4) was purchased for $\$ 6,000$ at a London auction in 1970. The Buddha and the chest-onchest were assigned to Auckland Museum by the Mackelvie Trust Board, forming a key part of the Asian art collection and the Landmarks: International Design and Decorative Arts collection, and became part of the permanent displays in the Asia Hall and Disney Hall of English Furniture (Gamble 1971). In 1984 Trustees Dr Lindo Ferguson and John Stacpoole purchased a 19th-century commode made by Anton Seuffert (1815-1887) at the Auckland auction house Cordy's for $\$ 6,750$ (Fig. 5) and this, too, went on display at Auckland Museum (Mackelvie Trust Board Papers 1984). These same two Trustees had previously purchased a pair of carved Māori panels from the house of Te Tiki a Tamamutu at Waitahanui, Taupo in 1981. The ethnologist and assistant director of the museum Dr David Simmons prepared an acquisition proposal for the panels, researching their provenance and history which was presented to the Mackelvie Trust Board in 1981. There was much discussion among the Trustees over the principle of owning Māori artefacts. It was suggested to the Trustees by Dr Simmons that "the pair of carvings would sell for $£ 40,000$ if they could be sold overseas and probably for $\$ 10,000$ if they were auctioned in New

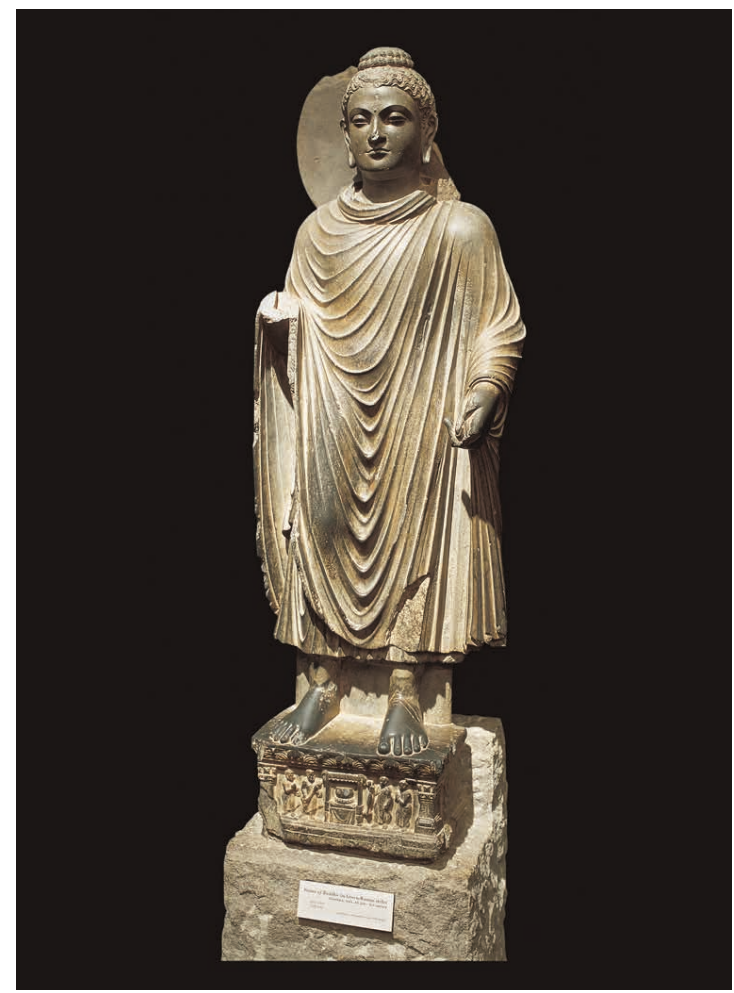

Figure 4. Buddha, AD 2nd-3rd century. Gandhara, North India. Mackelvie Collection, Auckland War Memorial Museum. M1067.

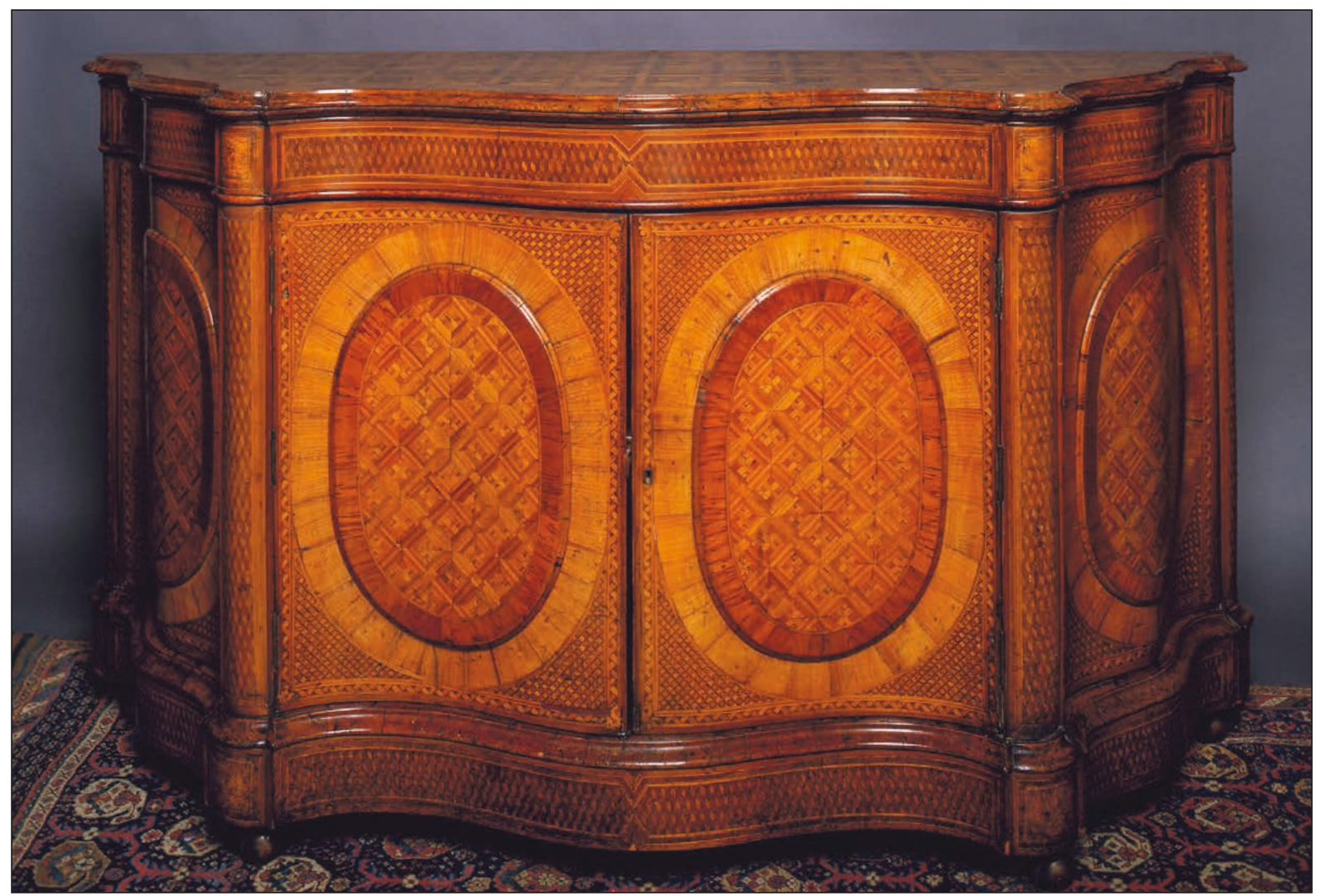

Figure 5. Commode of New Zealand native timbers, late 19th century. Attributed to Anton Seuffert. Mackelvie Collection, Applied Arts and Design, Auckland War Memorial Museum. F137. 
Zealand" (Mackelvie Trust Board Papers 1981). As a result, a decision was made to purchase the carvings for $\$ 5,000$ and retain them in New Zealand.

By the late 1980s, the Mackelvie Trust Board, returning to their interest in the fine arts collection at the Auckland Art Gallery, realised that they should shift their focus to more modern art works as the prices of 19th-century paintings became prohibitive (Mackelvie Trust Board Papers 1988). As a result, in the 1990s the Board's acquisition policy evolved to include early 20thcentury British works, which helped the collection gain a better representation of paintings from this period.

In 1997 Christopher Saines, then director of the Auckland Art Gallery, asked Mackelvie Trust Board Chairman John Wigglesworth (Chair from 1990 to 2011) to fund a part-time curatorial assistant dedicated to the Mackelvie collection (Mackelvie Trust Board Papers 1997). It was agreed that a major part of the Trustees' responsibility to maintain, exhibit and enhance the collection could be achieved by this dedicated Mackelvie curator. Mary Kisler, a specialist in Italian Renaissance art, was appointed to the position in May 1998. As part of the Trust's quarterly meetings, she presents reports on various activities related to the Mackelvie collection in the Auckland Art Gallery such as restoration projects, exhibitions, loans, and research on specific paintings.

It should be acknowledged that in the 21 st century all three institutions that house the Mackelvie collections are progressively developing and allowing free access to it as an ongoing process. This has involved the adding of new images and records, along with improving its online accessibility of this information to the public. This is a type of access that Mackelvie could only have dreamed of.

\section{CONCLUSION}

James Tannock Mackelvie's gift to Auckland was one of the most generous of the late 19th-century's bequests to civic institutions in New Zealand. Mackelvie chose to leave his collection to the city where his fortune had been made as a way of helping to bring about an improvement in the refinement and education of Aucklanders. The realisation of his vision would not have been possible without the significant role played by the Mackelvie Trust Board. Left in a difficult position upon Mackelvie's death with the requirement to build a gallery but not the means to do so, they have managed to steward the legacy into a world class collection of art, objects and books. Whilst the Auckland Free Public Library and Gallery had provided a safe repository for Mackelvie's art and book collection since 1887, it was not until 1929 with the opening of the Auckland War Memorial Museum that the Mackelvie decorative arts collection found a permanent home to further showcase the benefactor's diverse range of collecting interests. The first dedicated display at the museum was relocated in 2005 to establish 'The Mackelvie Collection' in the Decorative Arts Gallery on the first floor, and it remains to this day an integral component of the overall Auckland Museum experience (Fig. 6). This is due in part to the experience and expertise of the museum staff, but it also reflects the good stewardship of the Mackelvie Trust Board who remain dedicated to preserving Mackelvie's legacy for the enjoyment of future generations of Aucklanders and visitors to the city.

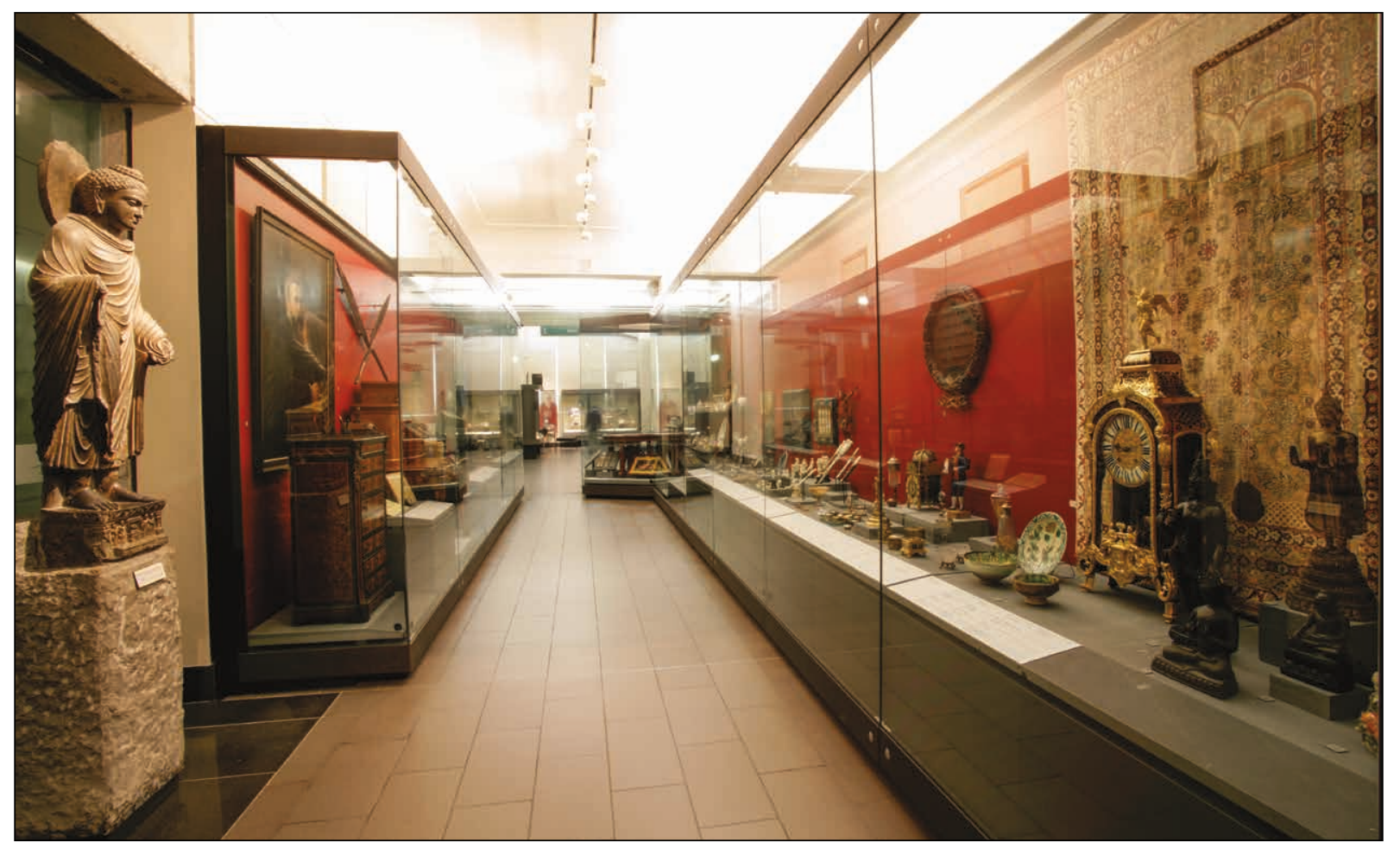

Figure 6. The Mackelvie Gallery, Auckland War Memorial Museum. Photograph by Krzysztof Pfeiffer. 


\section{REFERENCES}

Agreement on Mackelvie Art Collection. New Zealand Herald, March 111955.

Brown, Gordon H., 1981. New Zealand Painting, 1940-1960: Conformity and Dissension. Wellington: Queen Elizabeth II Arts Council of New Zealand.

Carroll, Penelope, 1994. Trust in Art. New Zealand Herald, August 251994.

Fairburn, A.R.D., 1947. Some reflections on New Zealand Painting. Landfall 1(1): 49-56.

Gamble, Brenda (ed.), 1971. New Zealand News. Art Gallery \& Museums Association of New Zealand 2(9): $11-17$.

Garrity, Tim, 1975. The Mackelvie Trust. Gallery Quarterly 60: 17-19.

James Tannock Mackelvie Papers, MS-51-142, Auckland War Memorial Museum Library.

The Mackelvie Collection: A centennial display of the Mackelvie gift of books (1985). EPH-2014-1954, Auckland War Memorial Museum Library.

Mackelvie Trust Board Papers, CL 06/10. E.H. McCormick Research Library, Auckland Art Gallery.
Mackelvie Trust Board Papers, NZMS 895, Series No. $2 / 1 ; 2 / 2 ; 2 / 3 ; 2 / 4 ; 2 / 5$. The Sir George Grey Special Collections, Auckland Central Library.

Powell, Arthur William Baden (ed.), 1967. The Centennial History of the Auckland Institute and Museum 1867-1967. Auckland: Auckland Institute and Museum.

Stacpoole, John, 1985. James Tannock Mackelvie and his Trust. In A. Bogle \& B. Muir, The Mackelvie Collection: a centenary exhibition, 1885-1985. The Mackelvie Trust: Auckland City Art Gallery; Auckland Institute and Museum, Auckland.

Stead, Oliver (ed.), 2001. 150 Treasures. Auckland: David Bateman/Auckland Museum.

Vennell, C.W., 1971. The Mackelvie Trust. Auckland: Wilson \& Horton Ltd.

Will of James Tannock Mackelvie, Westminster, London. 1877, December 21. BBAE, 1587, A48, 36, R8081626. Archives New Zealand, Auckland Regional Office.

Andrew McKay, University of Auckland. amck256@aucklanduni.ac.nz 
